\title{
Efficient Utilization of Energy with an Improved Farming System for Selected Semi-Arid Tropics
}

\author{
R.K. BANSAL, K.G. KSHIRSAGAR and R.D. SANGLE \\ International Crops Research Institute for the Semi-Arid Tropics (ICRISAT), P.O. \\ Patancheru-502 324, Andhra Pradesh (India)
}

(Accepted for publication 24 April 1986)

\begin{abstract}
Bansal, R.K., Kshirsagar, K.G. and Sangle, R.D., 1988. Efficient utilization of energy with an improved farming system for selected semi-arid tropics. Agric. Ecosystems Environ., 24: 381394.

The International Crops Research Institute for the Semi-Arid Tropics (ICRISAT), India, has developed an improved technology for the management of Vertisols. The results of testing of this technology in farmers' fields in India have shown that substantially higher yields can be achieved by an efficient application of available energy resources along with other high-value inputs. The technology does not depend upon a tractorized form of energy and improves the productivity of farm labor.
\end{abstract}

\section{INTRODUCTION}

The semi-arid tropics (SAT) cover a large area in Africa and some parts of Asia, Latin America and Australia. They represent a diversity of climate, soils, farming practices and socioeconomic conditions. The SAT are characterised by undependable and variable rainfall, and by soils generally poor in fertility and organic-matter content. Consequently, farming has a high risk of crop failures. Farmers are reluctant to invest in modern inputs such as fertilizers, seed of high-yielding varieties, efficient tools and implements, and plant protection measures, to increase crop production.

One of the greatest challenges for agricultural scientists in the SAT is to develop technically feasible and economically viable improved farming systems which can substantially increase yields and stabilise production. There are certain regions within SAT which have potential for growing at least one, and often two good crops annually due to relatively favourable rainfall distribution and quantity and the capacity of soils to store enough moisture ( Krantz et al., 1978). 
Farming Systems Research (FSR) at the International Crops Research Institute for the Semi-Arid Tropics (ICRISAT), near Hyderabad, India, has given considerable priority to evolving suitable techniques for the management of Vertisols, because of an apparent wide gap between potential and actual production from these soils (Kampen, 1982). Vertisols are found in large areas in India, Sudan, Ethiopia, Northern Australia and, to a smaller extent, in subSaharan Africa and Central America (Swindale, 1981). These soils develop cracks and become very hard when dry, and extremely sticky and difficult to work with when wet, thus allowing cultivation only in a limited range of moisture content (Krantz et al., 1978). Thus, farmers in medium- to high-rainfall regions in India traditionally fallow these soils during the rainy season.

This paper describes briefly the ICRISAT approach to increasing the productivity of deep Vertisols in the SAT regions by application of a wheeled tool carrier (WTC). Much of the paper is, however, devoted to the results obtained at three on-farm locations in India with respect to human and bullock labor utilization, and total energy output to input ratio for selected cropping systems in commonly followed traditional and ICRISAT-recommended improved soil and crop management practices.

\section{ICRISAT APPROACH}

Scientists at ICRISAT have evolved a set of broad principles for proper management of land and crop as well as efficient utilization of rain water and other resources. The new farming system, generally referred as Improved Vertisol Management Technology (IVMT) consists of the following three major components (Virmani et al., 1981 ):

(1) Land management practices that reduce runoff and erosion and provide adequate surface drainage to improve workability.

(2) Cropping systems and crop management practices that establish a crop early in the rainy season to make efficient use of rains.

(3) Implements for cultivation, seeding and fertilizer application that enable the required land and crop management practices to be carried out properly and timely.

The land and water management aspect, described in detail elsewhere (Krantz et al., 1978; Kampen, 1982 ) considers the small watershed as a unit on which surface treatment is imposed. The system involves construction of graded broadbeds and furrows (BBF) at $0.4-0.8 \%$ slope along the furrows The furrows made at a regular interval of $150 \mathrm{~cm}$ leave about $100-\mathrm{cm}$ wide, relatively flat and slightly raised $(10-15 \mathrm{~cm})$ beds. The beds, used for growing crops, appear as strips in the field separated by furrows. The furrows meant for drainage help in safe disposal of excess rain water to grassed waterways. They also provide pathways for the movement of wheels of farm machinery and draft animals. In practice the system works much like a controlled traffic 
tillage reported to be advantageous at other places (Schafer et al., 1981). The compaction due to the movement of wheels and oxen is restricted to the noncropped zone, and the cultivated area remains relatively friable (Klaij, 1983).

The work at ICRISAT has shown that two crops per year can be grown successfully on Vertisols, either as sequential crops or in an intercrop combination, in areas receiving a rainfall of $750 \mathrm{~mm}$ or more. However, to do so, it is essential to perform field operations at an optimum time considering climate and soil physical conditions (Kampen, 1982). It implies using improved farm implements and optimizing the use of available sources of farm power.

\section{WHEELED TOOL CARRIER (WTC)}

Farmers in SAT regions of India generally depend upon draft animals and human sources of energy for farm operations. They use wooden implements such as a non-inversion-type country plow and a blade harrow for seedbed preparation, a hand-metering type seeder for crop sowing, and a blade hoe for interrow weeding (Raghavan, 1960 ). These indigenous implements, referred to as 'traditional' in this paper, lack precision and speed and thus fail to make an efficient use of draft animals. In consequence, important operations such as sowing and interrow weeding are often delayed, resulting in an overall low productivity of the land.

In order to obtain precision and timeliness for farm operations, a wheeled tool carrier ( WTC) based animal-drawn farm machinery was developed. The WTC (Fig. 1) described in detail elsewhere (Bansal and Srivastava, 1981; Bansal and Thierstein, 1982 ) can perform various field operations by attaching appropriate implements to a toolbar at the rear of the machine. The WTC, usually pulled by a pair of oxen, provides flexibility for making suitable ad-

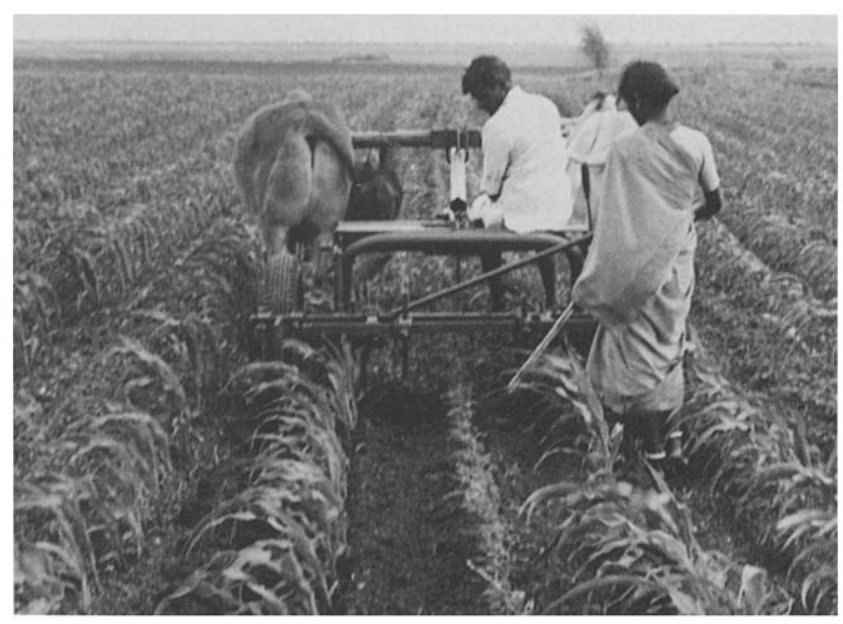

Fig. 1. An animal-drawn wheeled tool carrier (WTC) in use for interrow weeding. 
justments of working depth, lateral spacing between adjacent implements, and their orientation with respect to soil surface. A wide range of implements is available for tillage, sowing and fertilizer application, and interrow cultivation Additionally, by mounting a cart frame it can be used as a one-metric-tonne capacity cart.

Plowing in Vertisols is done as soon as possible after harvesting the postrainy season crop to alleviate difficulties in doing the same operation when the soil becomes dry. Primary tillage requires four passes of the WTC over the field as each time a narrow strip of the broadbed is cut to keep the draft requirement within pulling capacity of a pair of oxen. Secondary tillage is done during the dry season whenever opportunity is created by premonsoon rains. Sowing and fertilizer application is a combined operation completed in dry soil just before the seasonal rains are anticipated. One or two interrow weeding operations are performed between the 3rd and 6th week of crop growth and supplemented with at least one hand-weeding. Harvesting remains largely a manual job, whereas transportation of the produce could be done by using an ox cart. In a sequential cropping system a shallow cultivation precedes the sowing of the second crop.

Thus an animal-drawn WTC coupled with the BBF system of cultivation enables timely completion of farm operations. In this approach maximum emphasis is placed on the implement and its proper application rather than the source of power.

\section{ON-FARM VERIFICATION}

The analysis presented in this paper is based on data collected from three locations in India: Taddanpally (Andhra Pradesh), Farhatabad (Karnataka) and Begumgunj (Madhya Pradesh). These locations represent three agroclimatic regimes - relatively undependable rainfall regime at Farhatabad, a fairly dependable mean annual rainfall of about $750 \mathrm{~mm}$ at Taddanpally, and a high rainfall of $1300 \mathrm{~mm}$ at Begumgunj. At each location, several crops were grown under improved as well as traditional managements (Ghodake and Kshirsagar, 1983 ). The data used here, however, pertains only to major crops (Appendix I ). For the sake of a meaningful comparison only those crops which were important and common under traditional and improved managements were chosen.

Begumgunj differed from the other locations in that some farmers owned or had access to tractors. Hence, data from Begumgunj gives some comparison between fully tractor-operated fields, partially tractor-operated fields, and those managed entirely by bullock power. All the participating farmers used highyielding varieties, fertilizer, and improved soil management practices.

At each location, farm operations were conducted by the farmers using their own oxen. They also made decisions regarding choice of crops, hiring of labor 
for certain operations, plant protection measures, and so on. ICRISAT scientists who visited these experiments frequently, and one technical staff posted at each location, advised the State Department of Agriculture officials and farmers on various aspects of the IVMT. A full record was maintained for various inputs used under both improved and traditional systems.

\section{RESULTS AND DISCUSSION}

\section{Labor input}

Dryland agriculture in SAT regions of India is labor-intensive. In the experimental areas man-hours required per hectare varied from 571 to 892 depending upon crop and location (Table 1). The results show that the total labor input in an improved management is nearly the same or slightly more than that in traditional systems of cultivation. Under improved management, the use of a WTC reduces labor input for tillage and sowing operations. In both kinds of management, at least one hand-weeding was necessary to supplement mechanical interrow cultivation. Harvesting and threshing also remained

\section{TABLE 1}

Average human labor ( $m a n-h \mathrm{ha}^{-1}$ ) utilization for farm operations in selected cropping systems at three locations of on-farm testing in India

\begin{tabular}{|c|c|c|c|c|c|c|c|}
\hline & \multicolumn{2}{|l|}{$\begin{array}{l}\text { Taddanpally } \\
(1982-83)\end{array}$} & \multicolumn{2}{|l|}{$\begin{array}{l}\text { Farhatabad } \\
(1982-83)\end{array}$} & \multicolumn{3}{|l|}{$\begin{array}{l}\text { Begumgunj } \\
(1983-84)\end{array}$} \\
\hline & Traditional & Improved & Traditional & Improved & $\begin{array}{l}\text { Fully } \\
\text { tractorized } \\
\text { farm }\end{array}$ & $\begin{array}{l}\text { Tractor } \\
+ \\
\text { bullock } \\
\text { farm }\end{array}$ & $\begin{array}{l}\text { Fully } \\
\text { bullock } \\
\text { operated } \\
\text { farm }\end{array}$ \\
\hline $\begin{array}{l}\text { Tillage and } \\
\text { seedbed } \\
\text { preparation }\end{array}$ & 80 & 46 & $\begin{array}{c}54 \\
(42)\end{array}$ & $\begin{array}{c}72 \\
(76)\end{array}$ & 16 & 17 & 48 \\
\hline $\begin{array}{l}\text { Sowing and } \\
\text { fertilizer } \\
\text { application }\end{array}$ & $\begin{array}{l}55 \\
(37)\end{array}$ & 14 & $\begin{array}{c}34 \\
(33)\end{array}$ & 16 & 2 & 14 & 35 \\
\hline $\begin{array}{l}\text { Interrow } \\
\text { cultivation }\end{array}$ & $\begin{array}{l}240 \\
(86)\end{array}$ & $\begin{array}{l}196 \\
(90)\end{array}$ & $\begin{array}{l}179 \\
(80)\end{array}$ & $\begin{array}{l}219 \\
(91)\end{array}$ & $\begin{array}{c}30 \\
(42)\end{array}$ & $\begin{array}{c}501 \\
(89)\end{array}$ & $\begin{array}{c}67 \\
(58)\end{array}$ \\
\hline $\begin{array}{l}\text { Plant } \\
\text { protection }\end{array}$ & - & 22 & 28 & 29 & - & 26 & 17 \\
\hline $\begin{array}{l}\text { Harvesting } \\
\text { and threshing }\end{array}$ & $\begin{array}{l}315 \\
(59)\end{array}$ & $\begin{array}{l}405 \\
(77)\end{array}$ & $\begin{array}{l}276 \\
(62)\end{array}$ & $\begin{array}{l}270 \\
(92)\end{array}$ & $\begin{array}{l}578 \\
(49)\end{array}$ & $\begin{array}{l}334 \\
(56)\end{array}$ & $\begin{array}{l}479 \\
(69)\end{array}$ \\
\hline Total & $\begin{array}{l}690 \\
(60)\end{array}$ & $\begin{array}{l}683 \\
(72)\end{array}$ & $\begin{array}{l}571 \\
(61)\end{array}$ & $\begin{array}{l}606 \\
(83)\end{array}$ & $\begin{array}{l}626 \\
(47)\end{array}$ & $\begin{array}{l}892 \\
(71)\end{array}$ & $\begin{array}{l}646 \\
(57)\end{array}$ \\
\hline
\end{tabular}

Figures in brackets show the proportion of female labor as percentage of the total. 
mostly manual jobs. Therefore, the labor requirements for these operations were quite high and did not show a definite pattern of change.

Another significant point here is the contribution of women in the crop production systems. In the experimental area women contributed on an average $76 \%$ of the total labor input for hand-weeding and $66 \%$ for harvesting and threshing operations. The results indicate that under improved management systems the proportion of female labor is higher than traditional cultivation practices. Similar results were obtained by Ghodake and Kshirsagar (1983) by analysing results for a complete range of crops grown at the same locations. This is a desirable feature in India since it offers greater opportunity of employment to women in rural areas.

\section{Animal power utilization}

One of the objectives of on-farm testing of the Vertisol technology was to study the feasibility of using a WTC with oxen belonging to the farmers. These are often weaker than those used at the research station. Experience from various locations has shown that the tool carrier could be used effectively for all field operations using an average pair of oxen. At some locations, farmers complained of high draft for plowing with two moldboard plows of $22 \mathrm{~cm}$ width

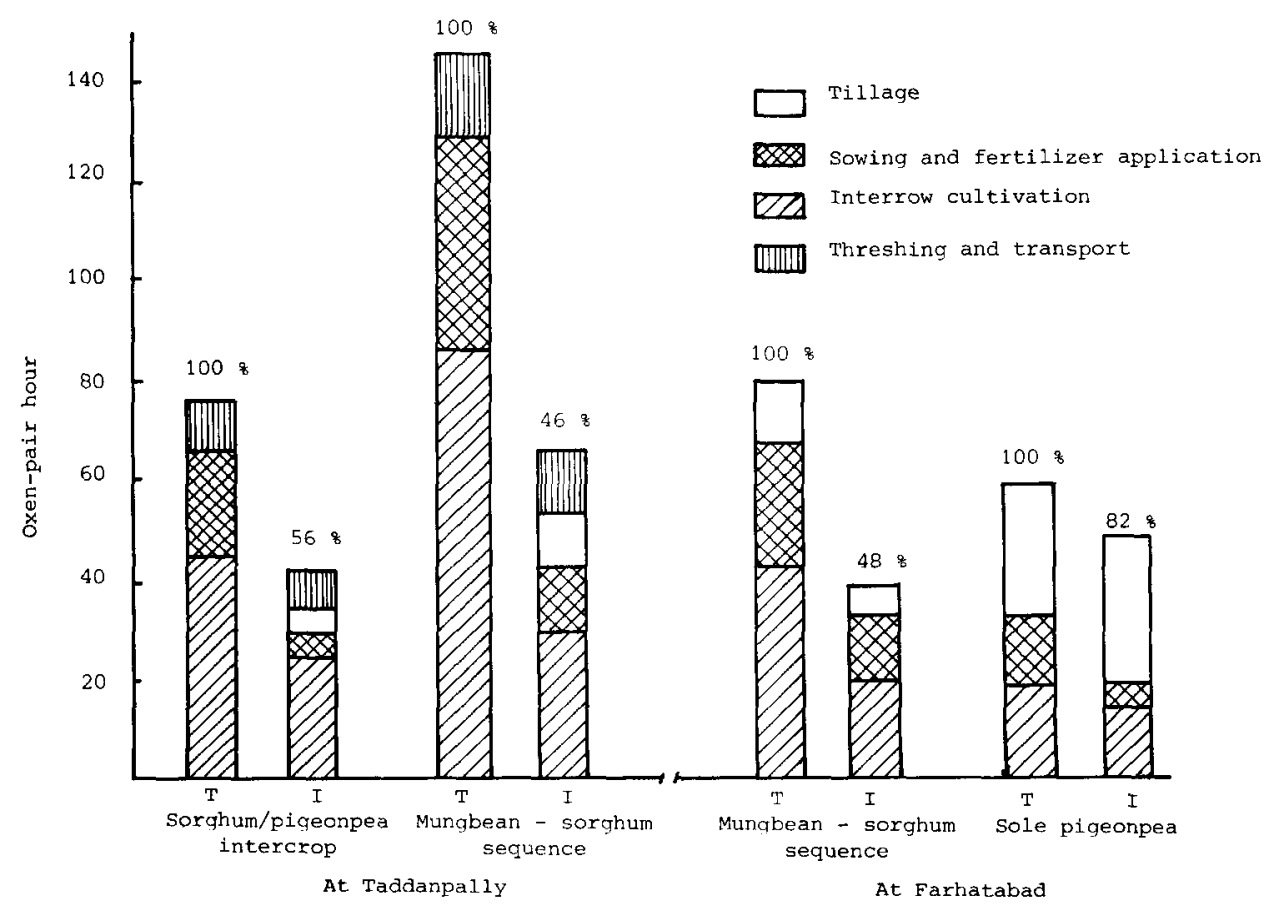

Fig. 2. Oxen-pair hours required under traditional (T) and improved (I) management. 
each and sowing four rows at a time. These problems could be solved by making suitable design improvements in the implements and adjusting them properly.

The use of a WTC in an improved management has resulted in $18-54 \%$ reduced input of total oxen pair-hours for all operations required for crop production (Fig. 2 ). In particular, the use of a WTC was beneficial for two-crops combinations where the overall time-saving was in the range of $44-54 \%$. Tillage and sowing operations with a WTC accounted for maximum gain because of greater speed and wider coverage by the machine under the improved management. Time-saving is especially important when a crop has to be sown within a short period before the onset of the monsoon, followed by another crop soon after harvesting of the previous one. The results also indicate the feasibility of using a pair of oxen to cover more area in a given time. Binswanger et al. (1979) concluded that one pair of relatively sturdy oxen used with a WTC in an improved management system can do the work of 2 or 3 pairs of small oxen with traditional implements.

Energy input and output

Ratio of energy output in the form of grain and the total of inputs in the traditional and improved management systems was taken as a measure of their efficiency. In the estimation of total energy output, straw as a by-product has been taken into account because, in animal-power based farming, straw also has an economic value as fodder. However, the primary focus of the IVMT is to increase grain production. Therefore, for comparing traditional and improved management systems, only the energy output through grain has been considered.

Energy input from the items used in the crop production process was calculated on the basis of the values given in Appendix II. In the improved system where a WTC and implements were used, indirect energy from machinery per hectare was calculated assuming an annual utilization of $580 \mathrm{~h}$ and 8 years life (Bansal and Thierstein, 1982 ). In traditional agriculture, most Indian farmers use a set of four implements (a country plow, a blade harrow, a handmetering type seeder, and a blade hoe ) made of hard wood and a few mildsteel components. Indirect energy from traditional implements was calculated on 4 years life. The gross weight of wood and steel was estimated as 106 and 12 $\mathrm{kg}$, respectively (Raghavan, 1960). Similarly, the indirect energy component from a tractor was estimated on the basis of its average annual utilization of $630 \mathrm{~h}$ in India (NCAER, 1980) and 10 years useful life.

Energy input and output values for selected crops grown at three locations are given in Tables 2, 3 and 4. The data presented in the tables give a good estimation of the energy picture for comparing two different techniques followed for growing selected crops in the SAT regions of India, but should not be taken in absolute terms. It is interesting to note that dryland agricultural 


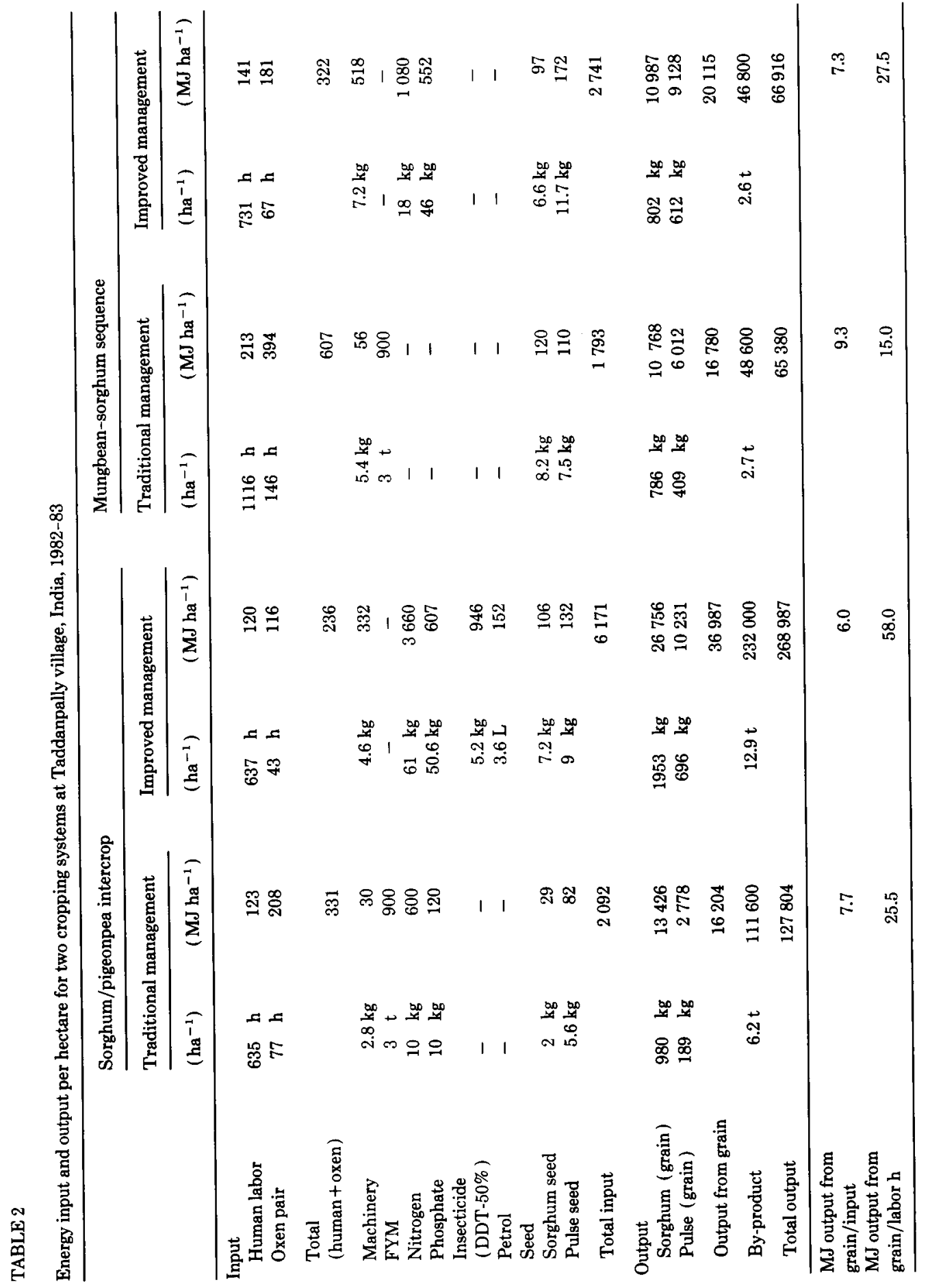




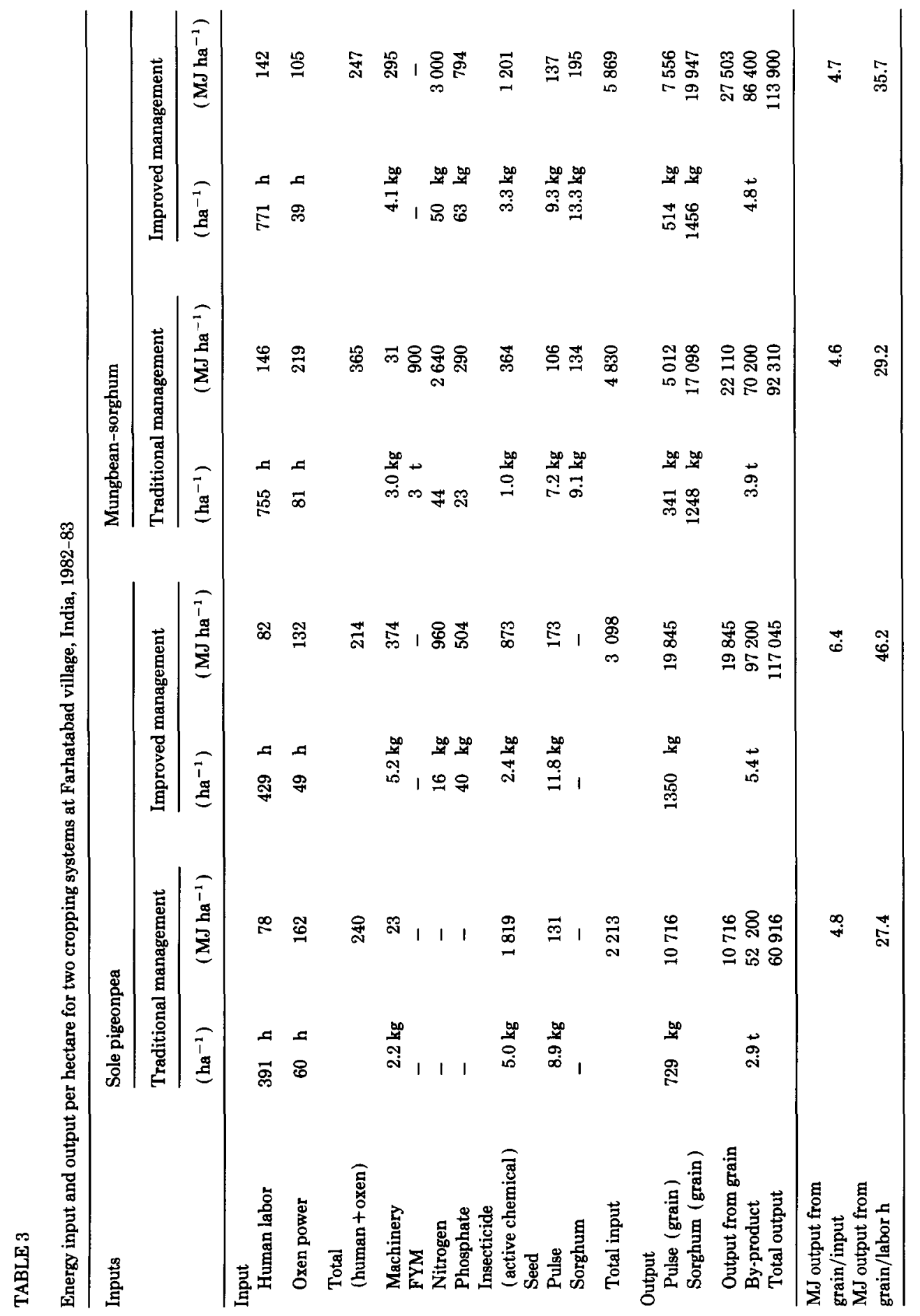


TABLE 4

Energy input and output per hectare for soybean/pigeonpea intercrop at Begumgunj village, India, 1983-84

\begin{tabular}{|c|c|c|c|c|c|c|}
\hline \multirow[t]{2}{*}{ Inputs } & \multicolumn{2}{|c|}{ Fully tractorized } & \multicolumn{2}{|c|}{$\begin{array}{l}\text { Tractor + bullock } \\
\text { operated farm }\end{array}$} & \multicolumn{2}{|c|}{$\begin{array}{l}\text { Fully bullock operated } \\
\text { farm }\end{array}$} \\
\hline & $\left(h a^{-1}\right)$ & $\left(\mathrm{MJ} \mathrm{ha}{ }^{-1}\right)$ & $\left(h a^{-1}\right)$ & $\mathrm{MJ} \mathrm{ha}^{-1}$ ) & $\left(h a^{-1}\right)$ & $\left(\mathrm{MJ} \mathrm{ha}^{-1}\right)$ \\
\hline \multicolumn{7}{|l|}{ Input } \\
\hline Human labor & $626 \mathrm{~h}$ & 125 & $892 \mathrm{~h}$ & 171 & $646 \mathrm{~h}$ & 127 \\
\hline Oxen pair & - & - & $33 \mathrm{~h}$ & 89 & $104 \mathrm{~h}$ & 281 \\
\hline Implements & $1.4 \mathrm{~kg}$ & 102 & $3.5 \mathrm{~kg}$ & 252 & $11.1 \mathrm{~kg}$ & 799 \\
\hline Tractor & $4.3 \mathrm{~kg}$ & 310 & $4.0 \mathrm{~kg}$ & 288 & - & - \\
\hline Diesel & $26.6 \mathrm{~L}$ & 1271 & $25.2 \mathrm{~L}$ & 1205 & - & - \\
\hline Nitrogen & $12 \mathrm{~kg}$ & 720 & $18 \mathrm{~kg}$ & 1080 & $8 \mathrm{~kg}$ & 480 \\
\hline Phosphate & $48 \mathrm{~kg}$ & 576 & $46 \mathrm{~kg}$ & 552 & $32 \mathrm{~kg}$ & 384 \\
\hline Potash & $12 \mathrm{~kg}$ & 80 & - & - & $8 \mathrm{~kg}$ & 54 \\
\hline Insecticide & & & & & & \\
\hline $\begin{array}{l}\text { (Endosulphon } \\
35 \% \text { ) }\end{array}$ & - & - & $1.5 \mathrm{~L}$ & 191 & - & - \\
\hline Seed & $100 \mathrm{~kg}$ & 1684 & $100 \mathrm{~kg}$ & 1684 & $100 \mathrm{~kg}$ & 1684 \\
\hline Soybean & $15 \mathrm{~kg}$ & 220 & $15 \mathrm{~kg}$ & 220 & $15 \mathrm{~kg}$ & 220 \\
\hline Pigeonpea & & & & & & \\
\hline Total & & 5088 & & 5731 & & 4029 \\
\hline \multicolumn{7}{|l|}{ Output } \\
\hline Soybean (grain) & $1250 \mathrm{~kg}$ & 21000 & $960 \mathrm{~kg}$ & 16128 & $811 \mathrm{~kg}$ & 13625 \\
\hline Pigeonpea (grain) & $625 \mathrm{~kg}$ & 9187 & $630 \mathrm{~kg}$ & 9261 & $558 \mathrm{~kg}$ & 8202 \\
\hline Output from grain & & 30187 & & 25389 & & 21827 \\
\hline By-product & $2.3 \mathrm{t}$ & 41400 & $2.0 \mathrm{t}$ & 36000 & $2.0 \mathrm{t}$ & 36000 \\
\hline Total output & & 71587 & & 61389 & & 57827 \\
\hline \multirow{2}{*}{$\begin{array}{l}\text { MJ output from } \\
\text { grain/input } \\
\text { MJ output from } \\
\text { grain/labor h }\end{array}$} & & 5.9 & & 4.4 & & 5.4 \\
\hline & & 48.4 & & 28.4 & & 33.8 \\
\hline
\end{tabular}

systems in SAT India are highly energy-efficient. The output-to-input ratio for all the crops is over 4.5. The energy output-to-input ratio depends to some extent on the level of productivity of the land. A marginal decline in this ratio is obvious at higher yields. Nevertheless, the ratio still remains favorable in all cases. This was probably due to high response obtained in terms of yield by making improvements in management and increasing certain inputs.

In an improved farming system utilizing animal power for growing sorghumbased crop combinations, the total energy input per hectare in India is far less than the energy input in non-irrigated sorghum production in Kansas, U.S.A. 
TABLE 5

Energy input and yield figures from selected locations in U.S.A., China and India

\begin{tabular}{llllll}
\hline Location & Sorghum & & & Soybean & \\
\cline { 2 - 3 } \cline { 5 - 6 } & $\begin{array}{l}\text { Yield } \\
\left(\mathrm{kg} \mathrm{ha}^{-1}\right)\end{array}$ & $\begin{array}{c}\text { Energy input } \\
\left(\mathrm{MJ} \mathrm{ha}^{-1}\right)\end{array}$ & $\begin{array}{l}\text { Yield } \\
\left(\mathrm{kg} \mathrm{ha}^{-1}\right)\end{array}$ & $\begin{array}{c}\text { Energy input } \\
\left(\mathrm{MJ} \mathrm{ha}^{-1}\right)\end{array}$ \\
\hline $\begin{array}{l}\text { Kansas, U.S.A. } \\
\begin{array}{l}\text { North-eastern } \\
\text { region, China }\end{array}\end{array}$ & 1840 & 25270 & & & \\
$\begin{array}{c}\text { Taddanpally and } \\
\text { Begumgunj, India }\end{array}$ & 1953 & 6170 & & 811 & 21215 \\
\hline
\end{tabular}

Sources ${ }^{\mathrm{a}}$ Bukantis (1980).

bazhong and Pimentel (1984).

at comparable yield (Table 5; Bukantis, 1980). Similarly, in China energy input reported for soybean production was five times greater than the energy input for the same crop in Begumgunj, India when yields differed only by oneand-half times. (Dazhong and Pimentel, 1984) . A close look at the production processes involved revealed that both in U.S.A. and China, high-level applications of fertilizer and farm machinery accounted for maximum energy input. These comparisons show the importance of the savings in indirect energy input from fossil fuel and excessive use of farm machinery.

In traditional management systems, farmers at Taddanpally tend to use very little or no inputs other than seed and field operations. Consequently, the yields from a sorghum/pigeonpea intercrop are much lower than those obtained from an improved management system. For a mungbean-sorghum sequence, yield differences were relatively small. At low levels of yield it appears that traditional systems are more energy-efficient (Table 2). However, double-cropping in those systems using traditional implements was feasible only on a small proportion of the cropped area and use of improved implements is inevitable when more area is brought under intensive cropping.

At Farhatabad, improved management gave higher yields and a better energy output-to-input ratio (Table 3 ) . At Begumgunj all farmers participating in the experiments used improved varieties and fertilizer. Fields cultivated partially or entirely by tractor power at Begumgunj produced higher yields for soybean/pigeonpea intercrop than those managed by bullock power alone ( Table 4 ). However, yield advantages cannot be attributed to the tractor conclusively. Yields obtained from eight fields of participating farmers varied from 550 to $1250 \mathrm{~kg} \mathrm{ha}^{-1}$ (CV 31\%) for soybean and from 300 to $1000 \mathrm{~kg} \mathrm{ha}^{-1}$ (CV 60\%) for pigeonpea. This is probably a reflection on the efficiency of management by individual farmers. Giles (1975) reported similar variations 
in results from introducing improved machinery in India. Higher coefficient of variation may be partly due to waterlogging in some fields during the rainy season having an adverse effect on crop performances.

The results also highlight the increased productivity of farm labor. The energy output per man-hour input was one and a half to two times more in an improved management as compared to the traditional system. The direct energy input from human labor and ox power in the improved management was also less by $30-40 \%$ compared to the traditional management system.

\section{CONCLUSIONS}

ICRISAT's approach to the management of Vertisols in the SAT regions of India shows promise of achieving a substantial increase in crop production. This system does not call for high investment in tractorized form of energy and can do well with relatively cheap power from draft animals and human labor. However, the use of efficient implements is required to obtain better quality and timeliness of operations. The use of improved implements saves direct energy input from human and oxen by $30-40 \%$ and makes it feasible to effectively cover more area with one pair of oxen.

The use of improved inputs such as high-yielding cultivars, moderate amounts of fertilizer, and plant protection measures, give good returns. This results in an overall high energy output-to-input ratio. Managerial factors which contribute to a higher output are: adequate plant population; good crop husbandry; and optimum utilization of soil moisture, by coinciding the vegetative phase with the rainy season. Under improved management, human labor is not displaced. In fact, other studies (Ghodake and Kshirsagar, 1983) have pointed out that when farmers change from a traditional, single crop per year system to a more intensive double-cropping system, human labor input increases, particularly for harvesting and threshing. It also increases human labor productivity so that the people are more gainfully employed.

\section{ACKNOWLEDGEMENTS}

The authors acknowledge the assistance received from various ICRISAT scientists involved in on-farm research. We are grateful to Mr. V.M. Mayande who assisted in data analysis and Mr. G.E. Thierstein for their constructive comments on the manuscript. 


\section{APPENDIX I}

Improved cropping systems selected for comparison at three on-farm research locations in India.

\begin{tabular}{|c|c|c|}
\hline Experiment location & Cropping system & $\begin{array}{l}\text { Percentage in the } \\
\text { experiment }\end{array}$ \\
\hline Taddanpally, Medak Dist. & Sorghum/pigeonpea intercrop & 45 \\
\hline Andhra Pradesh State (1982-83) & Mungbean-sorghum sequence & 33 \\
\hline Farhatabad, Gulbarga Dist. & Mungbean/sorghum sequence & 38 \\
\hline Karnataka State (1982-83) & Sole pigeonpea & $5^{a}$ \\
\hline \multicolumn{3}{|l|}{ Begumgunj, Raisen Dist., } \\
\hline Madhya Pradesh State & Soybean/pigeonpea intercrop & 63 \\
\hline
\end{tabular}

${ }^{a}$ Sole pigeonpea was an important crop in the traditional systems occupying $23 \%$ of the area.

\section{APPENDIX II}

Energy values for various inputs

1. Human labor

(a) Adult man $=0.22 \mathrm{MJ} \mathrm{h}^{-1}$ (Maheshwari et al., 1983)

(b) Women $=0.18 \mathrm{MJ} \mathrm{h}^{-1}$ (Maheshwari et al., 1983)

2. A pair of oxen $=2.7 \mathrm{MJ} \mathrm{h}^{-1}$ (Maheshwari et al., 1983)

3. Wooden implements $=10.5 \mathrm{MJ} \mathrm{kg}^{-1}$ (Maheshwari et al., 1983)

4. Steel tools and machinery $=72 \mathrm{MJ} \mathrm{kg}^{-1}$ (Maheshwari et al., 1983)

5. Tractor $=72 \mathrm{MJ} \mathrm{kg}^{-1}$

6. Diesel $=47.8 \mathrm{MJ} \mathrm{L}^{-1}$ (Carvinka, 1980)

7. Gasoline $=42.3 \mathrm{MJ} \mathrm{L}^{-1}$ (Carvinka, 1980)

8. Farm yard manure (FYM) $=300 \mathrm{MJ} \mathrm{t}^{-1}$ (Maheshwari et al., 1983)

9. Nitrogen $=60 \mathrm{MJ} \mathrm{kg}^{-1}$ ( Lockeretz, 1980)

10. Phosphate $=12 \mathrm{MJ} \mathrm{kg}^{-1}$ ( Lockeretz, 1980)

11. Potash $=6.7 \mathrm{MJ} \mathrm{kg}^{-1}$ (Lockeretz, 1980)

12. Insecticide $=363.8 \mathrm{MJ} \mathrm{kg}^{-1}$ of active ingredient (Pimentel, 1980)

13. Pigeonpea and mungbean seed and grain $=14.7 \mathrm{MJ} \mathrm{kg}^{-1}$

14. Soybean seed and grain $=16.8 \mathrm{MJ} \mathrm{kg}^{-1}$

15. Sorghum seed $=14.7 \mathrm{MJ} \mathrm{kg}^{-1}$

16. Sorghum grain $=13.7 \mathrm{MJ} \mathrm{kg}^{-1}$

17. Straw and crop residue $=18.0 \mathrm{MJ} \mathrm{kg}^{-1}$ of dry mass (Pandya, 1979)

\section{REFERENCES}

Bansal, R.K. and Srivastava, K.L., 1981. Improved animal drawn implements for farming in the semi-arid tropics. Agric. Mechan. Asia Afr. Lat. Am., 13 (1): 33-38.

Bansal, R.K. and Thierstein, G.E., 1982. Animal drawn multi-purpose tool carriers. Agric. Mechan. Asia Afr. Lat. Am., 13 ( 4 ): 27-36.

Binswanger, H.P., Ghodake, R.D. and Thierstein, G.E., 1979. Observations on the economics of tractors, bullocks, and wheeled tool carriers in the semi-arid tropics of India. In: Proc. Socioeconomic Constraints to Development of Semi-Arid Tropical Agriculture, 19-23 February 1979, International Crops Research Institute for the Semi-Arid Tropics, Patancheru, 210 pp. 
Bukantis, R., 1980. Energy input in sorghum production. In: D. Pimentel (Editor), Handbook of Energy Utilization in Agriculture. CRC Press, Boca Raton, FL, 106 pp.

Carvinka, V., 1980. Fuel and energy efficiency. In: D. Pimentel (Editor), Handbook of Energy Utilization in Agriculture, CRC Press, Boca Raton, FL, pp. 15-21.

Dazhong, W. and Pimentel, D., 1984. Energy inputs in agricultural systems of China. Agric. Ecosystems Environ., 11: 29-35.

Ghodake, R.D. and Kshirsagar, K.G., 1983. Employment generation potential of deep Vertisol technology in semi-arid tropical India. Presented at the Seminar on Rural Employment Policies in Asia, 7-10 December 1983, Asia Regional Team For Employment Promotion, Pattaya, Thailand.

Giles, G.W., 1975. The reorientation of agricultural mechanization for developing countries: part I. Agric. Mechan. Asia, 6 (2): 15-25.

Kampen, J., 1982. An approach to improved productivity on deep vertisols. Inf. Bull. 11, International Crops Research Institute for the Semi-Arid Tropics, Patancheru, 16 pp.

Klaij, M.C., 1983. Analysis and evaluation of tillage on an Alfisol in a semi-arid tropical region of India. Ph.D. Thesis, Soil Tillage Laboratory, Wageningen, The Netherlands, $147 \mathrm{pp}$.

Krantz, B.A., 1974. Cropping patterns for increasing the stabilizing agricultural production in the semi-arid tropics. In: Proc..Int. Workshop Farming Systems, 18-21 November 1974, International Crops Research Institute for the Semi-Arid Tropics, Patancheru.

Krantz, B.A., Kampen, J. and Virmani, S.M., 1978. Soil and water conservation and utilization for increased food production in the semi-arid tropics. ICRISAT J. Art. 30, ICRISAT, Patancheru, Available from Farming Systems Research Program.

Lockeretz, W., 1980. Energy input for nitrogen, phosphorus and potash fertilizers. In: D. Pimentel (Editor ), Handbook of Energy Utilization on Agriculture. CRC Press, Boca Raton, FL, pp. 23-24.

Maheshwari, R.C., Bohra, C.P. and Chandra, P., 1983. Standardization of heat values and power outputs of various renewable and non-renewable energy sources. Presented at the XX Annual Convention of Indian Society of Agricultural Engineers, 5-7 March 1983, G.B. Pant University of Agriculture and Technology, Pantnagar.

National Council of Applied Economic Research, 1980. Productivity, and income. In: Implications of Tractorization on Employment, Vol. 1. NCEAR, New Delhi, pp. 74-100.

Pandya, A.C., 1979. Energy in agriculture. Tech. Bull. CIAE/81/20, Central Institute of Agricultural Engineering, Bhopal.

Pimentel, D., 1980. Energy inputs for the production, formulation, packaging, and transport of various pesticides. In: D. Pimentel (Editor), Handbook of Energy Utilization in Agriculture. CRC Press, Boca Raton, FL, pp. 46-48.

Raghavan, D., (Editor), 1960. Indigenous agricultural implements of India. Indian Council of Agricultural Research, New Delhi, 401 pp.

Schafer, R.L., Young, S.C. and Hendrick, J.G., 1981. Control concepts for tillage systems, ASAE Pap. 81-1601, National Tillage Machinery Laboratory, USDA Agricultural Service, Auburn, AL.

Swindale, L.D., 1981. An overview of ICRISAT's research on the management of deep black soils. In: Proc. Sem. Management of Deep Black Soils for Increased Production of Cereals, Pulses, and Oilseeds, 21 May 1981, New Delhi. International Crops Research Institute for the SemiArid Tropics, Patancheru, pp. 17-29.

Virmani, S.M., Willey, R.W. and Reddy, M.S., 1981. Problems, prospects, and technology for increasing cereal and pulse production from deep black soils. In: Proc. Sem. Management of Deep Black Soils for Increased Production of Cereals, Pulses and Oilseed, 21 May 1981, New Delhi. International Crops Research Institute for the Semi-Arid Tropics, Patancheru, pp. 2136. 